\title{
ASSESSMENT OF THE RISK OF EXPOSURE TO CADMIUM AND LEAD AS A RESULT OF THE CONSUMPTION OF LOW-FAT DAIRY PRODUCTS BY EXPECTANT AND LACTATING WOMEN
}

\author{
Anna Winiarska-Mieczan $\bowtie$ \\ Department of Bromatology and Food Physiology, University of Life Sciences in Lublin \\ Akademicka 13, 20-950 Lublin, Poland
}

\begin{abstract}
Background. The study aimed to assess the risk related to consumption of low-fat dairy products by expectant and lactating women.

Material and methods. A survey was used to verify the popularity of such products among expectant and lactating women and then the content of $\mathrm{Cd}$ and $\mathrm{Pb}$ in low-fat dairy products was determined.

Results. In the group of expectant women consuming dairy products, nearly $93 \%$ of the respondents consumed low-fat dairy products, while among lactating women the result was $90 \%$. Both the expectant and lactating women mostly preferred milk and fruit yoghurt. It was found that the studied low-fat products did not contain more $\mathrm{Cd}$ and $\mathrm{Pb}$ than their standard counterparts.

Conclusion. Taking into account the intake of low-fat milk and dairy products declared by respondents, such products must be regarded safe in terms of $\mathrm{Cd}$ and $\mathrm{Pb}$ content. The maximum supply of $\mathrm{Cd}$ and $\mathrm{Pb}$ for both groups of women did not exceed $3 \%$ TWI and $2 \% \mathrm{BMDL}_{10}$.
\end{abstract}

Key words: lactating women, expectant women, low-fat dairy products, $\mathrm{Cd}, \mathrm{Pb}$, risk of exposure

\section{INTRODUCTION}

In Poland and in other European countries the energy value of a diet is normally higher than recommended by nutrition guidelines, which results in an increased percentage of overweight and obese people [Jarosz and Rychlik 2009]. As a consequence, for health reasons, it is necessary to reduce the consumption of high energy foods. Therefore, both consumers and dieticians have been increasingly interested in low-fat foods [Pirozzo et al. 2003]. Low-fat products available for sale are usually the counterparts of traditional food products. Studies show that low energy food products are very popular, in particular among young women [Flaczyk et al. 2006]. They most frequently choose dairy products, and especially yoghurts [Flaczyk et al. 2006]. Dairy products form an important element of the daily diets of Polish consumers with regard to high nutritional value, and in particular the content of complete protein and calcium [Górska-Warsewicz 2005]. Expectant women should consume at least 3-4 servings of $200 \mathrm{ml}$ of milk a day [Waszkowiak et al. 2010], while lactating women -3 servings [Wojtyła et al. 2011]. This product can be partially replaced by other dairy products [Waszkowiak et al. 2010]. Studies by Hyżyk and Sokalska

凶anna.mieczan@up.lublin.pl 
[2011] showed that in Poland pregnant women most frequently consume milk, yoghurts and cheese. The available literature does not contain any data regarding the popularity of low-fat dairy products in diets of expectant and lactating women, but supposedly women in those periods of their lives consume lowcalorie products to prevent excessive weight gain. In European countries low-fat dairy products are also recommended during pregnancy and in the period of lactation [Brantsæter et al. 2012, WHO 2001].

Numerous data suggests that milk and dairy products can be a source of toxic metals for humans [Birghila et al. 2008, Starska et al. 2011]. The content of metals in milk depends primarily on the environmental exposure of cows: complexes, formed by metals and organic matter, are assimilated by plants, which in turn are consumed by animals and penetrate into milk [Fels-Klerx et al. 2011]. The literature available both in Poland and throughout the world lacks the results of studies concerning the content of toxic metals in low-fat products. Considering that such products are very popular and can also be consumed by particularly vulnerable consumers, such as expectant and lactating women, they must be monitored for their toxic metals content - most of all cadmium and lead. The dynamically developing nervous system of the foetus and infant is most exposed to these metals which also disturb bone-forming processes [Sughis et al. 2011], can inhibit intellectual development and cause anaemia and rickets [D'Souza et al. 2003]. Significantly, a positive correlation between the concentration of toxic metals in children and the occurrence of autism has been observed [Bradstreet et al. 2003]. However, mother's milk can also be a source of heavy metals for an infant. The content of these elements in breast milk reflects the level of environmental pollution and the woman's diet [Gundacker et al. 2002, Nishijo et al. 2002]. The content of metals in food most often consumed by lactating women must be continuously monitored.

The study aimed to: 1) assess the popularity of low-fat dairy products among expectant and lactating women; 2) check whether they could be a significant source of cadmium and/or lead since the author's survey demonstrated that such products were consumed by the definite majority of women.

\section{MATERIAL AND METHODS}

\section{Survey}

The survey was carried out in Lublin, Świętokrzyskie and Łódź Voivodeships from May to June 2011. Data was collected from 674 expectant women $(255$ from Lublin Voivodeship, 235 from Świętokrzyskie Voivodeship and 184 from Łódź Voivodeship) and 725 lactating women (326 from Lublin Voivodeship, 280 from Świętokrzyskie Voivodeship and 119 from Łódź Voivodeship). The respondents were divided into 5 age groups: younger than 20, 20-25, 26-30, 31-35 and above 35 years of age (Table 1). An identical survey questionnaire for both groups of women consisted of 18 questions, mostly single-choice, but there were also multiple-choice questions. The questions referred to consumption of low-fat dairy products, among other things, the reasons for choosing this type of products and their preferred types. In addition, over seven successive days the women had to complete a table giving the size of servings of low-fat dairy products consumed.

\section{Study material}

The content of $\mathrm{Cd}$ and $\mathrm{Pb}$ was studied in 186 lowfat dairy products: 36 natural yoghurts, 41 fruit yoghurts, 12 kefirs, 38 quark cheeses, 14 yellow cheeses and 45 samples of pasteurised cow's milk (Table 2). The products were bought in food stores in Lublin, Kielce and Lódź in September and October 2012, still within their shelf-life. The samples were frozen at a temperature of $-18^{\circ} \mathrm{C}$ until chemical analyses.

\section{Chemical analyses}

Thawed at room temperature, the samples were mixed manually. Afterwards, the samples of different consistency (quark cheeses and yellow cheeses and fruit yoghurts) were homogenised. Every sample was taken in three repetitions: with a volume of ca. $3 \mathrm{ml}$ (milk) or weight of ca. $3 \mathrm{~g}$ (other products). The samples, dried at $65^{\circ} \mathrm{C}$ over the following $24 \mathrm{~h}$ and then at $105^{\circ} \mathrm{C}$ over $24 \mathrm{~h}$, underwent combined mineralisation in a muffle furnace at a temperature of $450^{\circ} \mathrm{C}$ over $12 \mathrm{~h}$, using hydrogen peroxide as the oxidant. The resulting ash was dissolved in $1 \mathrm{M} \mathrm{HNO}_{3}$.

The content of $\mathrm{Cd}$ and $\mathrm{Pb}$ was determined by GF AAS technique in a Varian Spectr AA 880 apparatus 
Winiarska-Mieczan A., 2014. Assessment of the risk of exposure to cadmium and lead as a result of the consumption of low-fat dairy products by expectant and lactating women. Acta Sci. Pol., Technol. Aliment. 13(2), 213-223.

Table 1. Profile of the analysed population of women

\begin{tabular}{|c|c|c|c|c|c|c|c|c|c|c|c|c|}
\hline & \multicolumn{10}{|c|}{ Age of the mothers, years } & \multirow{2}{*}{\multicolumn{2}{|c|}{ Total }} \\
\hline & \multicolumn{2}{|c|}{$<20$} & \multicolumn{2}{|c|}{$20-25$} & \multicolumn{2}{|c|}{$26-30$} & \multicolumn{2}{|c|}{$31-35$} & \multicolumn{2}{|c|}{$>35$} & & \\
\hline & $n$ & $\%$ & $n$ & $\%$ & $n$ & $\%$ & $n$ & $\%$ & $n$ & $\%$ & $n$ & $\%$ \\
\hline Expectant women & 112 & & 123 & & 151 & & 165 & & 123 & & 674 & \\
\hline \multicolumn{13}{|l|}{ BMI } \\
\hline Correct mass & 107 & 96 & 117 & 95 & 141 & 93 & 158 & 96 & 119 & 97 & 642 & 95 \\
\hline Overweight & 5 & 4 & 6 & 5 & 10 & 7 & 7 & 4 & 4 & 3 & 32 & 5 \\
\hline Eating dairy products & 112 & 100 & 121 & 98 & 150 & 99 & 161 & 98 & 118 & 96 & 662 & 98 \\
\hline No dairy products consumption & 0 & 0 & 2 & 2 & 1 & 1 & 4 & 2 & 5 & 4 & 12 & 2 \\
\hline Eating low-fat dairy products & 110 & $98^{*}$ & 119 & $98^{*}$ & 139 & $93^{*}$ & 140 & $87 *$ & 110 & $93^{*}$ & 618 & 93 \\
\hline Once a week or occasionally & 44 & $40 * *$ & 38 & $32 * *$ & 48 & $35^{* *}$ & 51 & $36^{* *}$ & 46 & $42 * *$ & 227 & 37 \\
\hline Several times a week & 35 & $32 * *$ & 47 & $39 * *$ & 45 & $32 * *$ & 54 & $39 * *$ & 34 & $31 * *$ & 215 & 35 \\
\hline Every day & 31 & $28 * *$ & 34 & $29 * *$ & 46 & $33 * *$ & 35 & $25 * *$ & 30 & $27^{* *}$ & 176 & 28 \\
\hline 3-4 times daily & 13 & $42 * * *$ & 17 & $50 * * *$ & 25 & $54 * * *$ & 19 & $54 * * *$ & 22 & $73 * * *$ & 96 & 55 \\
\hline 1-2 times daily & 18 & $58 * * *$ & 17 & $50 * * *$ & 21 & $46^{* * *}$ & 16 & $46^{* * *}$ & 8 & $27 * * *$ & 80 & 45 \\
\hline $\begin{array}{l}\text { No low-fat dairy products } \\
\text { consumption }\end{array}$ & 2 & $2^{*}$ & 2 & $2^{*}$ & 11 & $7 *$ & 21 & $13^{*}$ & 8 & $7 *$ & 44 & 7 \\
\hline Lactating women & 123 & 100 & 151 & 100 & 153 & 100 & 146 & 100 & 152 & 100 & 725 & 100 \\
\hline \multicolumn{13}{|l|}{ BMI } \\
\hline Correct mass & 101 & 82 & 125 & 83 & 122 & 80 & 122 & 84 & 129 & 84 & 599 & 83 \\
\hline Overweight & 22 & 18 & 26 & 17 & 31 & 20 & 24 & 16 & 23 & 16 & 126 & 17 \\
\hline Eating dairy products & 93 & 76 & 105 & 70 & 96 & 63 & 104 & 71 & 92 & 61 & 490 & 68 \\
\hline No dairy products consumption & 30 & 24 & 46 & 30 & 57 & 37 & 42 & 29 & 60 & 39 & 235 & 32 \\
\hline Eating low-fat milk products & 74 & $80^{*}$ & 93 & $89 *$ & 73 & $76^{*}$ & 62 & $60^{*}$ & 85 & $92 *$ & 387 & 79 \\
\hline Once a week or occasionally & 30 & $40 * *$ & 34 & $37 * *$ & 15 & $21 * *$ & 15 & $24 * *$ & 20 & $24 * *$ & 114 & 29 \\
\hline Several times a week & 25 & $34 * *$ & 20 & $21 * *$ & 39 & $53 * *$ & 34 & $55^{* *}$ & 28 & $33 * *$ & 146 & 39 \\
\hline Every day & 19 & $26^{* *}$ & 39 & $42 * *$ & 19 & $26^{* *}$ & 13 & $21 * *$ & 37 & $43^{* *}$ & 127 & 32 \\
\hline 3-4 times daily & 8 & $42 * * *$ & 22 & $56 * * *$ & 10 & $53 * * *$ & 7 & $54 * * *$ & 24 & $65^{* * *}$ & 71 & 56 \\
\hline 1-2 times daily & 11 & $58 * * *$ & 17 & $44 * * *$ & 9 & $47 * * *$ & 6 & $46^{* * *}$ & 13 & $35^{* * *}$ & 56 & 44 \\
\hline $\begin{array}{l}\text { No low-fat dairy products } \\
\text { consumption }\end{array}$ & 19 & $20 *$ & 12 & $11^{*}$ & 23 & $24^{*}$ & 42 & $40^{*}$ & 7 & $8^{*}$ & 103 & 21 \\
\hline
\end{tabular}

*Total women eating dairy products was assumed as $100 \%$.

**Total women eating low-fat dairy products was assumed as $100 \%$.

***Total women eating low-fat dairy products every day was assumed as $100 \%$. 
Winiarska-Mieczan A., 2014. Assessment of the risk of exposure to cadmium and lead as a result of the consumption of low-fat dairy products by expectant and lactating women. Acta Sci. Pol., Technol. Aliment. 13(2), 213-223.

Table 2. Characteristics of analysed low-fat dairy products

\begin{tabular}{|c|c|c|c|c|c|c|}
\hline & Natural yoghurt & Fruit yoghurt & Kefir & Quark cheese & Yellow cheese & Milk \\
\hline$n$ & 56 & 76 & 16 & 38 & 14 & 65 \\
\hline \multicolumn{7}{|l|}{ Made in } \\
\hline Poland & 31 & 27 & 16 & 14 & 7 & 35 \\
\hline France & 20 & 22 & 0 & 8 & 5 & 18 \\
\hline Germany & 5 & 19 & 0 & 12 & 1 & 10 \\
\hline Czech Republic & 0 & 8 & 0 & 4 & 1 & 2 \\
\hline \multicolumn{7}{|l|}{ "Light" annotation } \\
\hline Yes & 44 & 62 & 10 & 38 & 14 & 0 \\
\hline No & 12 & 14 & 6 & 0 & 0 & 65 \\
\hline $0 \%$ fat products & 12 & 14 & $8^{*}$ & 0 & 0 & 65 \\
\hline
\end{tabular}

*Some products were labelled as $0 \%$ fat + "light".

(atomisation in a graphite furnace, the Zeeman background correction, pure gas - argon). The content of Cd was determined at $\lambda=228.8 \mathrm{~nm}$, with $4 \mathrm{~mA}$ and $0.5 \mathrm{~nm}$ spectral band pass (LOD $0.01 \mathrm{mg} / \mathrm{kg}$, LOQ $0.02 \mathrm{mg} / \mathrm{kg}$ ). The deviation of duplicate measurement was below $5.3 \%$, the mean recovery rate was $96 \%$. The content of lead was determined at $\lambda=217.0 \mathrm{~nm}$, with $10 \mathrm{~mA}$ and $1 \mathrm{~nm}$ spectral band pass (LOD - 0.209 $\mathrm{mg} / \mathrm{kg}, \mathrm{LOQ}-0.419 \mathrm{mg} / \mathrm{kg}$ ). The deviation of duplicate measurement was below $5 \%$, the mean recovery rate $-95 \%$. In order to make the calibration line, standard solutions of $\mathrm{Cd}$ and $\mathrm{Pb}$ were procured from Merck (Germany). Quality control of analytical measurements was performed using blank samples and certified reference materials: IRMM-804 Rice Flour (Cd) and BCR-063R Skimmed Milk Powder (Pb).

\section{Calculation and statistical analysis}

The content of $\mathrm{Cd}$ and $\mathrm{Pb}$ in cow's milk was calculated per $100 \mathrm{ml}$, while in other samples - per $100 \mathrm{~g}$ of the product. Based on the declared maximum weekly intake of respective groups of products by expectant and lactating women (Table 3), the daily supply of $\mathrm{Cd}$ and $\mathrm{Pb}$ was calculated. Based on the daily supply of $\mathrm{Cd}$ and $\mathrm{Pb}$ in the studied products, the TWI (Tolerable Weekly Intake) percentage was calculated for $\mathrm{Cd}$ and $\mathrm{BMDL}_{10}$ (Benchmark Dose Lower
Confidence Limit) for $\mathrm{Pb}$, assuming respectively $2.5 \mu \mathrm{g} / \mathrm{kg}$ of body weight/week [EFSA $2012 \mathrm{a}$ ] and $4.4 \mu \mathrm{g} / \mathrm{kg}$ of body weight/week $(0.63 \mu \mathrm{g} / \mathrm{kg}$ of body weight/day) [EFSA 2012 b]. The average body weight declared by the respondents $-73 \mathrm{~kg}$ during pregnancy and $60 \mathrm{~kg}$ during lactation - was used in the calculation. The results were analysed with the use of STATISTICA 6.0 software.

\section{RESULTS}

\section{Expectant women}

On average, $98 \%$ of expectant women taking part in the study consumed dairy products, out of which nearly $93 \%$ of respondents admitted choosing low-fat dairy products (Table 1). Nearly all women younger than 20 and aged 20-25 declared they consumed lowfat products. Women aged $31-35$ (87\% of the respondents) least frequently declared choosing such products. On average, $28 \%$ of the respondents consumed low-fat products every day, and 55\% declared consuming 3-4 servings per day. Expectant women consumed such products primarily in order to prevent excessive weight gain (94\% of answers) and due to their favoured taste (indicated by $55 \%$; Fig. 1). A few other answers mentioned commercials, common trends and attractive packaging. Regardless of their age, women most often 
Winiarska-Mieczan A., 2014. Assessment of the risk of exposure to cadmium and lead as a result of the consumption of low-fat dairy products by expectant and lactating women. Acta Sci. Pol., Technol. Aliment. 13(2), 213-223.

Table 3. Results of low-fat dairy products analysis

\begin{tabular}{|c|c|c|c|c|c|c|}
\hline & Natural yoghurt & Fruit yoghurt & Kefir & Quark cheese & Yellow cheese & Milk \\
\hline$n$ & 36 & 41 & 12 & 38 & 14 & 35 \\
\hline \multicolumn{7}{|l|}{$\mathrm{Cd}, \mu \mathrm{g} / 100 \mathrm{~g}$} \\
\hline Mean & 0.155 & 0.556 & 0.150 & 0.267 & 0.308 & 0.093 \\
\hline Minimum & ND & ND & ND & 0.097 & 0.017 & ND \\
\hline Maximum & 0.237 & 1.132 & 0.094 & 0.783 & 0.968 & 0.994 \\
\hline Median & 0.071 & 0.567 & 0.560 & 0.189 & 0.270 & 0.600 \\
\hline SD & 0.109 & 0.089 & 0.119 & 0.087 & 0.092 & 0.130 \\
\hline SEM & 0.317 & 0.218 & 0.292 & 0.384 & 0.487 & 0.652 \\
\hline Variance analysis & 0.503 & 0.474 & 2.953 & 1.182 & 1.421 & 0.277 \\
\hline \multicolumn{7}{|l|}{ Percentile } \\
\hline $90 \%$ & 0.000 & 0.648 & 0.064 & 0.177 & 0.050 & 0.073 \\
\hline $10 \%$ & 0.409 & 0.204 & 0.185 & 0.126 & 0.249 & 0.787 \\
\hline \multicolumn{7}{|l|}{$\mathrm{Pb}, \mu \mathrm{g} / 100 \mathrm{~g}$} \\
\hline Mean & 0.535 & 0.651 & 0.533 & 0.791 & 0.942 & 0.419 \\
\hline Minimum & ND & ND & 0.009 & 0.329 & ND & ND \\
\hline Maximum & 0.859 & 0.791 & 0.644 & 0.954 & 1.413 & 0.649 \\
\hline Median & 0.050 & 0.129 & 0.030 & 0.068 & 0.065 & 0.013 \\
\hline $\mathrm{SD}$ & 0.059 & 0.104 & 0.017 & 0.064 & 0.011 & 0.039 \\
\hline SEM & 0.160 & 0.033 & 0.038 & 0.341 & 0.158 & 0.127 \\
\hline Variance analysis & 0.129 & 0.011 & 0.004 & 0.929 & 1.595 & 0.048 \\
\hline \multicolumn{7}{|l|}{ Percentile } \\
\hline $90 \%$ & 0.039 & 0.012 & 0.421 & 1.090 & 1.305 & 0.559 \\
\hline $10 \%$ & 0.748 & 0.690 & 0.524 & 0.456 & 0.158 & 0.079 \\
\hline
\end{tabular}

$\mathrm{ND}$ - not detectable, SD - standard deviation, SEM - standard error of the means.

declared choosing fruit yoghurts. Also, products such as milk and quark cheese were very popular (Fig. 2). Women who did not consume dairy products $(2 \%)$ claimed they did not like the taste of this food.

\section{Lactating women}

On average, $68 \%$ of lactating women declared that they consumed dairy products (Table 1). In this group, low-fat products were consumed by $90 \%$ of women aged 20-25 and over 35 years of age, including $40 \%$ women eating such products every day. In the whole studied population, $79 \%$ of the respondents consumed low-fat products, including $32 \%$ of women consuming them every day (56\%, 3-4 servings per day). Most frequently, the reason for consuming such products was the intention to lose weight ( $97 \%$ of answers) and favoured taste (65\%) (Fig. 1). The women preferred fruit yoghurts, quark cheese and milk (Fig. 2). Women, who did not consume dairy products $(32 \%$ of the respondents) pointed exclusively to the risk of cow's 


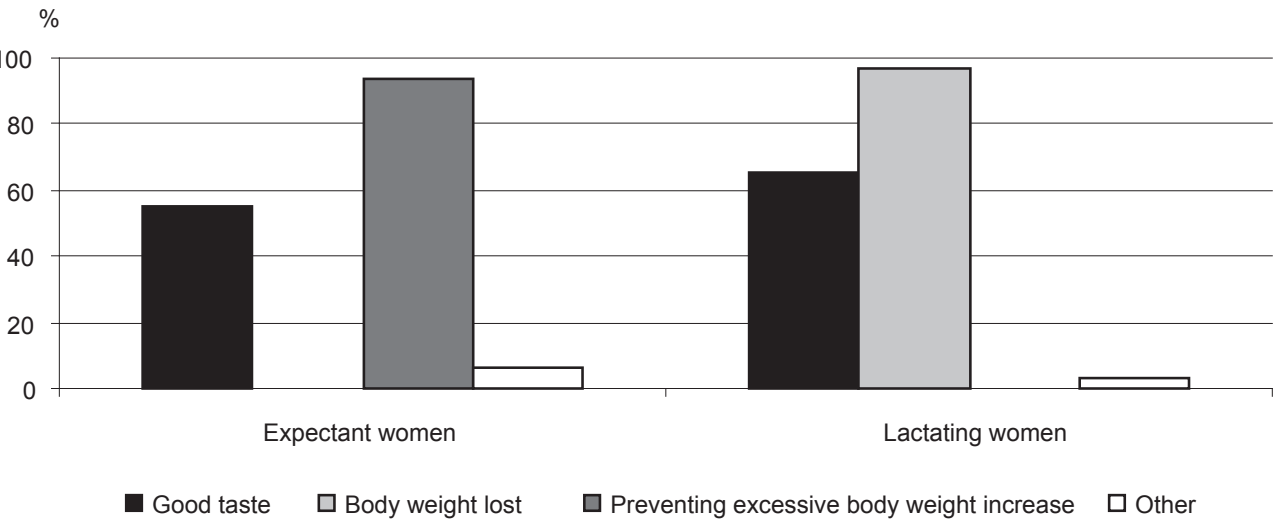

Fig. 1. Reasons for eating low-fat dairy products

A

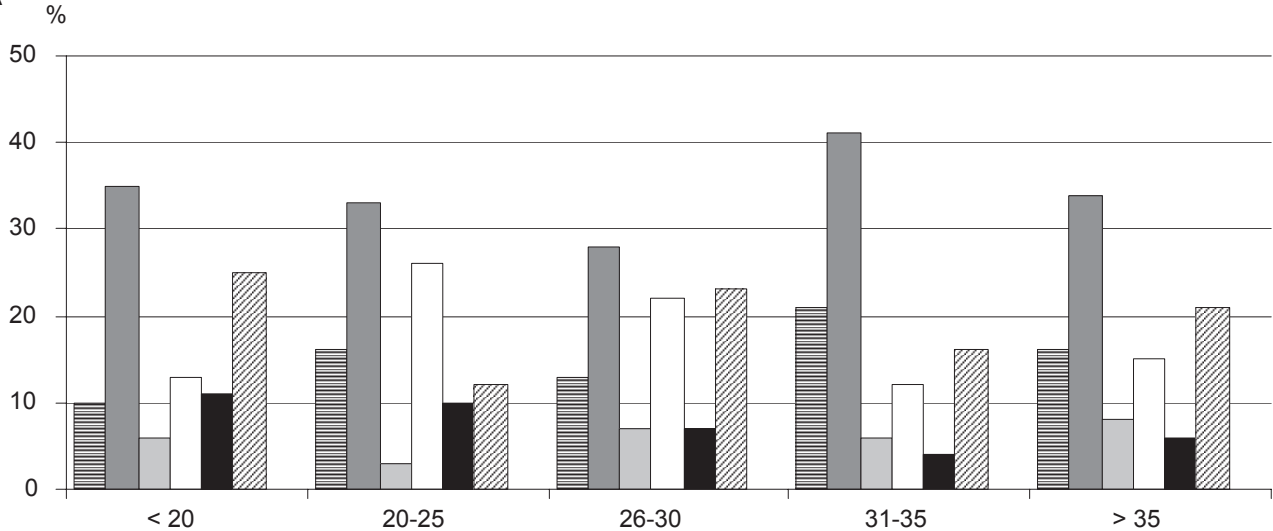

Age of women

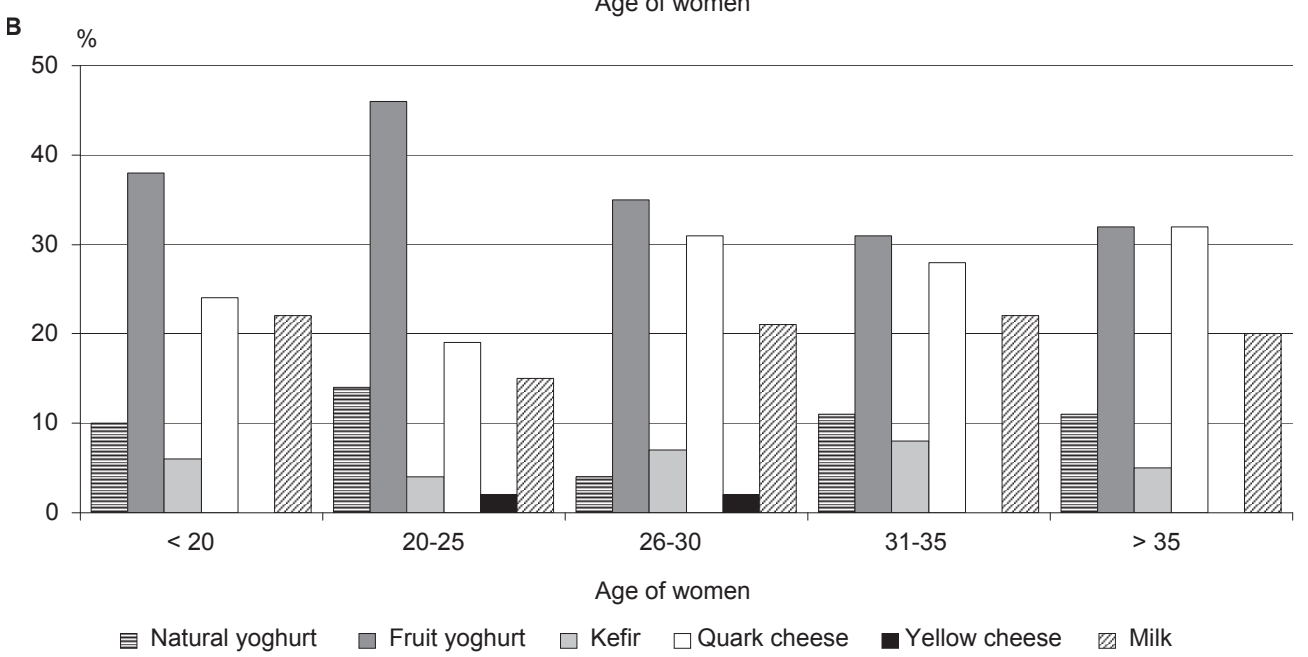

Fig. 2. Eating dairy low-fat products by expectant (A) and lactating (B) women 
Winiarska-Mieczan A., 2014. Assessment of the risk of exposure to cadmium and lead as a result of the consumption of low-fat dairy products by expectant and lactating women. Acta Sci. Pol., Technol. Aliment. 13(2), 213-223.

milk protein allergy occurring in the infant or were themselves allergic to cow's milk.

\section{Content of $\mathrm{Cd}$ and $\mathrm{Pb}$ in low-fat dairy products}

Table 3 presents the content of $\mathrm{Cd}$ and $\mathrm{Pb}$ in the studied low-fat dairy products. The highest content of $\mathrm{Cd}$ was found in fruit yoghurt - more than $0.5 \mu \mathrm{g} / 100 \mathrm{~g}$ of fresh weight, and in quark cheese and yellow cheese - about $0.3 \mu \mathrm{g} / 100 \mathrm{~g}$. The least $\mathrm{Cd}$ was found in natural yoghurt (ca. $0.15 \mu \mathrm{g} / 100 \mathrm{~g}$ ) and milk (less than $0.1 \mu \mathrm{g} / 100 \mathrm{~g}$ ). The highest content of $\mathrm{Pb}$ was identified in quark cheese $(0.79 \mu \mathrm{g} / 100 \mathrm{~g})$ and yellow cheese $(1.43 \mu \mathrm{g} / 100 \mathrm{~g})$, while the least $\mathrm{Pb}$ was found in milk (ca. $0.42 \mu \mathrm{g} / 100 \mathrm{~g}$ ). The safest products in terms of the content of both toxic metals were natural yoghurt and milk.

\section{Intake of $\mathrm{Cd}$ and $\mathrm{Pb}$ with low-fat dairy products}

The weekly supply of metals was calculated (Table 4) taking into account the weekly intake of the studied products, as declared by the respondents, and the average content of $\mathrm{Cd}$ and $\mathrm{Pb}$ in such products (determined by chemical methods). The maximum intake of products declared by both expectant and lactating women was used to assess the risk. It was found that the intake of the studied low-fat dairy products would not cause the tolerable safe intake level of $\mathrm{Cd}$ and $\mathrm{Pb}$ to be exceeded. The least amount of $\mathrm{Cd}$ is supplied with kefir (for expectant women it is $0.17 \%$ TWI, and for lactating women $-0.31 \% \mathrm{TWI}$ ) and yellow cheese $(0.17 \%$ TWI for expectant women and $0.41 \%$ TWI for lactating women). The highest amount of $\mathrm{Cd}$ can be supplied to both expectant and lactating women with fruit yoghurt (ca. 2.3\% TWI and 3\% TWI, respectively), while to lactating women - fruit yoghurt and quark cheese (more than $8 \%$ TWI). The highest $\% \mathrm{BMDL}_{10}$ of $\mathrm{Pb}$ in both groups of women was identified in the case of fruit yoghurt consumption (ca. 1.5-2.0\%), and the lowest in the case of yellow cheese (ca. $0.3 \%-$ expectant women and $0.7 \%$ - lactating women) and kefir $(0.3 \%$ - expectant women and $0.6 \%$ - lactating women).

Table 4. Maximum weekly consumption of dairy low-fat products and $\mathrm{Cd}$ and $\mathrm{Pb}$ intake

\begin{tabular}{|c|c|c|c|c|c|c|c|c|c|c|c|c|}
\hline & \multicolumn{6}{|c|}{ Expectant women } & \multicolumn{6}{|c|}{ Lactating women } \\
\hline & \multicolumn{2}{|c|}{$\begin{array}{c}\text { weekly } \\
\text { consumption } \\
\text { of products } \\
\text { g }\end{array}$} & \multicolumn{2}{|c|}{$\begin{array}{c}\text { maximum } \\
\text { weekly } \\
\text { intake }^{b} \\
\mu g\end{array}$} & \multirow[t]{2}{*}{$\begin{array}{c}\% \\
\mathrm{TWI}^{\mathrm{c}}\end{array}$} & \multirow{2}{*}{$\frac{\%}{\mathrm{BMDL}_{10}{ }^{\mathrm{c}}}$} & \multicolumn{2}{|c|}{$\begin{array}{l}\text { weekly } \\
\text { consumption } \\
\text { of products }^{\mathrm{a}} \\
\mathrm{g}\end{array}$} & \multicolumn{2}{|c|}{$\begin{array}{c}\text { maximum } \\
\text { weekly } \\
\text { intake }^{\mathrm{b}} \\
\mu \mathrm{g}\end{array}$} & \multirow[t]{2}{*}{$\begin{array}{c}\% \\
\text { TWI }^{\mathrm{d}}\end{array}$} & \multirow[t]{2}{*}{$\begin{array}{c}\% \\
\mathrm{BMDL}_{10}\end{array}$} \\
\hline & maximum & mean & $\mathrm{Cd}$ & $\mathrm{Pb}$ & & & maximum & mean & $\mathrm{Cd}$ & $\mathrm{Pb}$ & & \\
\hline Natural yoghurt & 400 & 150 & 0.62 & 2.14 & 0.34 & 0.67 & 500 & 250 & 0.78 & 2.68 & 0.52 & 1.01 \\
\hline Fruit yoghurt & 750 & 350 & 4.17 & 4.88 & 2.28 & 1.52 & 820 & 350 & 4.56 & 5.34 & 3.00 & 2.02 \\
\hline Kefir & 200 & 100 & 0.31 & 1.07 & 0.17 & 0.33 & 300 & 200 & 0.46 & 1.60 & 0.31 & 0.61 \\
\hline Quark cheese & 150 & 100 & 0.40 & 1.19 & 0.22 & 0.37 & 300 & 175 & 0.80 & 2.37 & 0.53 & 0.90 \\
\hline Yellow cheese & 100 & 100 & 0.31 & 0.94 & 0.17 & 0.29 & 200 & 100 & 0.62 & 1.88 & 0.41 & 0.71 \\
\hline Milk & 1000 & 650 & 0.93 & 4.19 & 0.62 & 1.30 & 1000 & 500 & 0.93 & 4.19 & 0.62 & 1.59 \\
\hline
\end{tabular}

${ }^{\mathrm{a} O n}$ the basis of the questionnaire survey.

${ }^{\mathrm{b}} \mathrm{Calculated}$ on the basis of the maximum consumption of products and mean level of $\mathrm{Cd}$ and $\mathrm{Pb}$.

${ }^{c}$ Mean expectant women body weight was assumed as $73 \mathrm{~kg}$.

dMean lactating women body weight was assumed as $60 \mathrm{~kg}$.

TWI - Tolerable Weekly Intake for Cd was determined at $2.5 \mu \mathrm{g} / \mathrm{kg}$ of body weight/week [EFSA $2012 \mathrm{a}$ ].

$\mathrm{BDML}_{10}-$ Benchmark Dose Lower Confidence Limit for $\mathrm{Pb}$ was determined at $0.50 \mu \mathrm{g} / \mathrm{kg}$ of body weight per day [EFSA $2012 \mathrm{~b}$ ]. 


\section{DISCUSSION}

Milk and dairy products should be consumed by expectant and lactating women mostly because such products are the fundamental and a very good source of calcium both for the woman and the baby [Waszkowiak et al. 2010]. Expectant and lactating women have an increased requirement of calcium [Sobczak and Jabłoński 2007]. Laskey et al. [1998] demonstrated that already after 3 months of lactation the level of calcium in the bones of women decreases, which is connected with the penetration of this component into milk. Thus, the intake of calcium and Vit. D, both with food and food supplements, should be increased. Studies by Bachanek and Nakonieczna-Rudnicka [2009] showed that $92 \%$ of expectant women declared they regularly consumed dairy products. According to Godala et al. [2012] only less than $2 \%$ of expectant inhabitants of Łódź did not consume milk and dairy products. Similar effects were observed by Wojtyła et al. [2011]. According to the author's own studies, on average $98 \%$ of expectant women and $68 \%$ of lactating women declared that they consumed milk and dairy products, including more than $90 \%$ of expectant women and nearly $80 \%$ of lactating women consuming low-fat products. Expectant and lactating women consumed these products due to their reduced energy value, thus in order to prevent excessive weight gain. The studies revealed a close relationship between consuming considerable amounts of full-fat dairy products and excessive BMI, while consuming low-fat dairy products had the opposite effect [Snijder et al. 2007, Beydoun et al. 2008]. In addition, dairy products are one of the fundamental sources of unsaturated trans fatty acids in the human diet [Combe et al. 2000] which are particularly hazardous for the foetus and infants [Jamioł-Milc et al. 2010]; thus, partial removal of fat simultaneously reduces the amount of trans acids.

Fat is the carrier of taste [Sasaki et al. 2007], so products from which fat was partially or wholly removed are usually characterised by weaker sensory values compared to their traditional counterparts. Studies by Jaworska [2007] showed that the level of acceptance of low-fat quark cheese among consumers was significantly lower. Also, Kaminarides et al. [2007] found that yoghurts produced from lowfat milk were characterised by weaker organoleptic properties than yoghurts produced from milk containing more fat. In the author's survey $55 \%$ of expectant women and $65 \%$ of lactating women claimed that lowfat products have a very favourable taste, not worse than that of traditional dairy products.

The most popular dairy products among different groups of people are cow's milk and yoghurts [Waszkowiak et al. 2010, Winiarska-Mieczan et al. 2007]. Also, the author's survey showed that both expectant and lactating women mostly preferred milk and fruit yoghurts. The eagerness to consume yoghurts was probably a result of their taste but it can be also attributed to the fact that they are carry-away foods which can be easily taken, for example, to work or for a walk. Yoghurts, which are fermented products, reduce the absorption of cholesterol and increase the bioactivity of calcium, which is better absorbed in an acidic environment [Pfeuffer and Schrezenmeir 2007].

It was found that the studied low-fat products did not contain more $\mathrm{Cd}$ and $\mathrm{Pb}$ than their standard counterparts from Poland and other countries (Fig. 3). The literature available both in Poland and throughout the world lacks the results of studies concerning the content of heavy metals in low-fat products. However, Enb et all. [2009] found that in processed cow's milk and buffalo milk containing more fat (butter, cream) the concentration of $\mathrm{Cd}$ and $\mathrm{Pb}$ was higher than in products containing less fat (yoghurt, milk). Opposite results were obtained by Radzymińska et al. [2008], who claimed that the smallest content of $\mathrm{Cd}$ and $\mathrm{Pb}$ was found in butter. However, the results obtained by the above-quoted authors are not sufficient to determine a relationship between the content of fat in foodstuffs and the content of toxic metal in them. Studies to be carried by our team in the future will compare the content of toxic metals in low-fat dairy products and with that in their traditional counterparts. The author's own studies revealed that quark cheese and yellow cheese contained the highest amount of $\mathrm{Pb}$. The findings of Starska et al. [2011], who studied products with standard fat content, were similar. In the author's own studies the safest products in terms of the content of these metals were natural yoghurt and pasteurised milk. The studies involving Romanian products with a standard content of fat, carried out by Dobrinas et al. [2010], revealed that the lowest amount of $\mathrm{Cd}$ and $\mathrm{Pb}$ was contained in pasteurised 
Winiarska-Mieczan A., 2014. Assessment of the risk of exposure to cadmium and lead as a result of the consumption of low-fat dairy products by expectant and lactating women. Acta Sci. Pol., Technol. Aliment. 13(2), 213-223.

$\mathrm{Cd}$

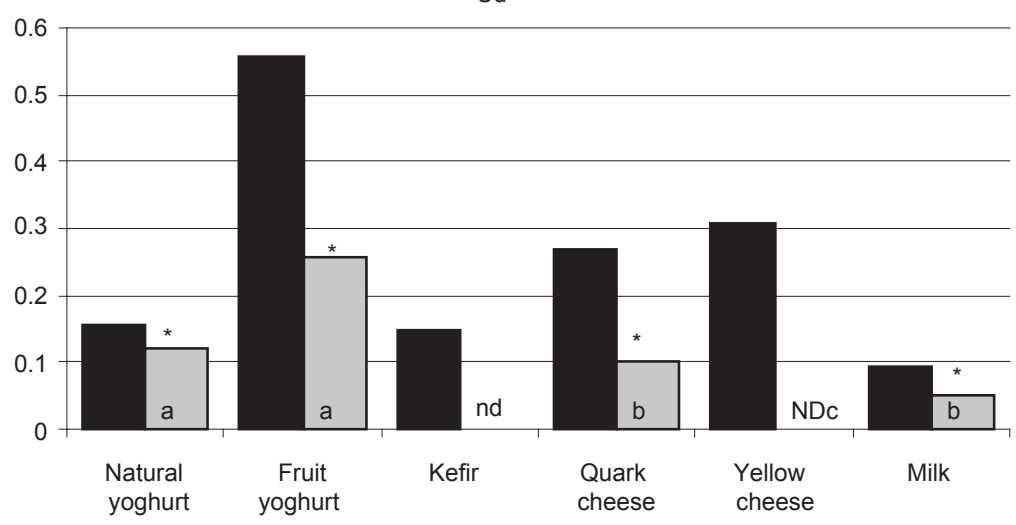

$\mathrm{Pb}$

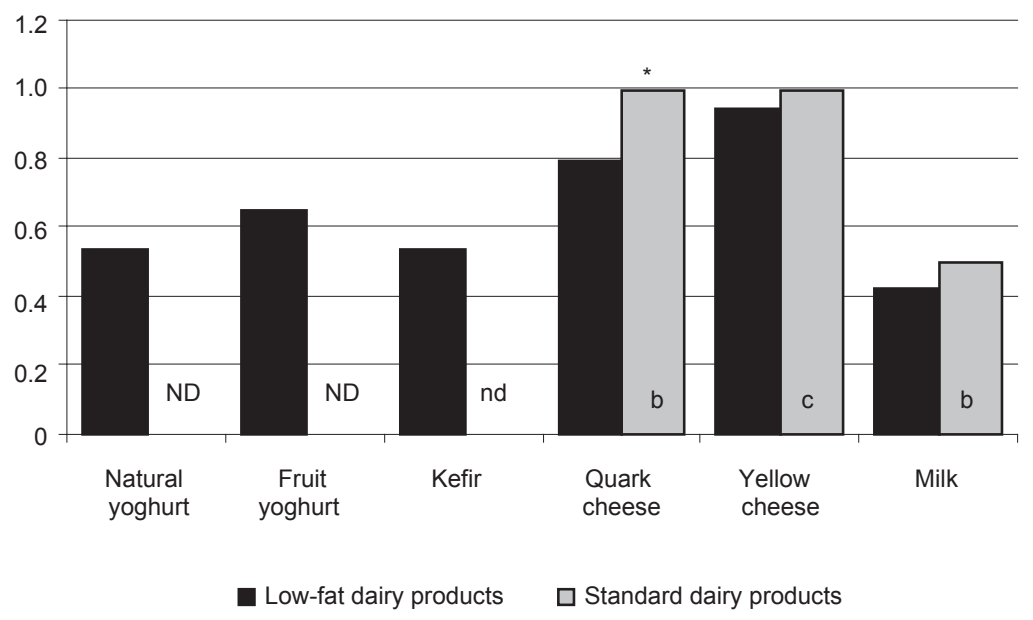

Fig. 3. Comparison of the concentrations of $\mathrm{Cd}$ and $\mathrm{Pb}$ in low-fat (this study) and standard dairy products, $\mu \mathrm{g} / 100 \mathrm{~g}$ : a - Dobrinas et al. 2010, b - Starska et al. 2011, c - Szkoda and Żmudzki 1996; ND - not detectable, nd - no data; * - significant versus low-fat dairy products $(P<0.05)$

milk, whereas fruit yoghurt contained more cadmium than natural yoghurt (on average $0.115 \mathrm{mg}$ vs 0.259 $\mathrm{mg} / \mathrm{kg}$ ). Polish studies showed that milk and dairy products are safe for consumers in terms of toxic metals content [Starska et al. 2011, Gabryszuk et al. 2008].

\section{CONCLUSION}

Based on the author's own findings, it can be claimed that the studied low-fat products did not contain more $\mathrm{Cd}$ and $\mathrm{Pb}$ than their standard counterparts. Taking into account the intake of low-fat milk and dairy products declared by respondents, such products must be regarded as safe in terms of $\mathrm{Cd}$ and $\mathrm{Pb}$ content. The maximum supply of $\mathrm{Cd}$ for both groups of women did not exceed 3\% TWI, while that of $\mathrm{Pb}-2 \%$ $\mathrm{BMDL}_{10}$. Dairy products, and mostly low-fat products, should be promoted among expectant and lactating women. At the same time, it must be remembered that defatted dairy products are completely devoid of fat, so they also lack lipophilic vitamins, mostly vitamin $\mathrm{D}$ which is responsible for the correct intestinal absorption of calcium [Sunyecz 2008]. Conventional wisdom should not equate low-fat products and defatted products. 


\section{REFERENCES}

Bachanek T., Nakonieczna-Rudnicka M., 2009. Nawyki żywieniowe kobiet w ciąży [Dietary habits of pregnant women]. Czas. Stomatol. 62 (10), 800-808 [in Polish].

Beydoun M.A., Gary T.L., Caballero B.H., Lawrence R.S., Cheskin L.J., Wang Y., 2008. Ethnic differences in dairy and related nutrient consumption among US adults and their association with obesity, central obesity, and the metabolic syndrome. Am. J. Clin. Nutr. 87, 1914-1925.

Birghila S., Dobrinas S., Stanciu G., Soceanu A., 2008. Determination of major and minor elements in milk through ICP-AES. Environ. Eng. Manag. J. 7 (6), 805-808.

Bradstreet J., Geier D.A., Kartzinel J.J., Adams J.B., Geier M.R., 2003. A case-control study of mercury burden in children with autistic spectrum disorders. J. Am. Phys. Surg. 3, 76-79.

Brantsæter A.L., Olafsdottir A.S., Forsum E., Olsen S.F., Thorsdottir I., 2012. Does milk and dairy consumption during pregnancy influence fetal growth and infant birthweight? A systematic literature review. Food Nutr. Res. 56: 20050. doi.org/10.3402/fnr.v56i0.20050.

Combe N., Boué C., Entressangles B., 2000. Consommation en acides trans et risqué cardio-vasculaire: Etiude Aqitaine. Oléagineux Corps Gras Lipides 1, 30-34.

D’Souza H.S., Menezes G., Venkatesh T., 2003. Role of essential trace minerals on the absorption of heavy metals with special reference to lead. Indian J. Clin. Biochem. 18, 154-160.

Dobrinas S., Stanciu G., Roncea F., Cucui O., 2010. Quality control of milk and dairy products. Ovidius Univ. Annal. Chem. 21 (1), 91-95.

EFSA, 2012 a. Cadmium dietary exposure in the European population. EFSA J. 10, 2551-2588.

EFSA, 2012 b. Lead dietary exposure in the European population. EFSA J. 10, 2831-2890.

Enb A., Abou Donia M.A., Abd-Rabou N.S., Abou-Arab A.A.K., El-Senaity M.H., 2009. Chemical composition of raw milk and heavy metals behavior during processing of milk products. Global Vet. 3 (3), 268-275.

Fels-Klerx van der I., Römkens P., Franz E., van Raamsdonk L., 2011. Modeling cadmium in the feed chain and cattle organs. Biotechnol. Agron. Soc. Environ. 15 (S1), 53-59.

Flaczyk E., Kobus J., Korczak J., 2006. Assessment of consumption of "light" food by students. Acta Sci. Pol., Technol. Aliment. 5 (1), 173-181.

Gabryszuk M., Słoniewski K., Sakowsk T.I., 2008. Macroand microelements in milk and hair of cows from conventional vs. organic farms. Anim. Sci. Pap. Rep. 26 (3), 199-209.

Godala M., Pietrzak K., Łaszek M., Gawron-Skarbek A., Szatko F., 2012. Udział produktów mlecznych jako źródła jodu w diecie kobiet ciężarnych [The contribution of dairy products to iodine intake in pregnant women's diet]. Probl. Hig. Epidemiol. 91 (4), 560-563 [in Polish].

Górska-Warsewicz H., 2005. Rozwój rynku produktów mleczarskich [Development of dairy products market]. Przem. Spoż. 10, 20-23.

Gundacker C., Pietschnig B., Wittmann J.K., Lischka A., Salzer H., Hohenauer L., Schuster E., 2002. Lead and mercury in breast milk. Pediatrics 110, 873-878.

Hyżyk K.A., Sokalska N., 2011. Ocena zmian masy ciała u kobiet w ciąży [The evaluation of body mass changes in pregnant women]. Nowiny Lek. 80 (3), 174-177 [in Polish].

Jamioł-Milc D., Stachowska E., Chlubek D., 2010. Skutki spożywania trans nienasyconych kwasów thuszczowych w okresie ciąży i laktacji [Effects of dietary trans fatty acids in pregnancy and lactation]. Ann. Acad. Med. 56 (1), 21-27 [in Polish].

Jarosz M., Rychlik E., 2009. Obesity - an increasingly widespread problem. Family Med. Prim. Care Rev. 11 (3), 647-653.

Jaworska D., 2007. Jakość sensoryczna serów twarogowych o zróżnicowanej zawartości tłuszczu [Sensory quality of regular and reduced-fat quarks]. Żywn. Nauka Technol. Jakość 2 (51), 40-50.

Kaminarides S., Stamou P., Massouras T., 2007. Comparison of the characteristics of set type yogurt made from ovine milk of different fat content. Int. J. Food Sci. Technol. 42, 1019-1028.

Laskey M.A., Prentice A., Hanratty L.A., Jarjou L.M.A., Dibba B., Beavan S.R., Cole T.J., 1998. Bone changes after 3 mo of lactation: influence of calcium intake, breast-milk output, and vitamin D-receptor genotype. Am. J. Clin. Nutr. 67, 685-692.

Nishijo M., Nakagawa H., Honda R., Tanabe K., Saito S., Teranishi K., Tawara K., 2002. Effects of maternal exposure to cadmium on pregnancy and breast milk. Occup. Environ. Med. 59, 394-397.

Pfeuffer M., Schrezenmeir J., 2007. Milk and the metabolic syndrome. Obes. Rev. 8, 109-118.

Pirozzo S., Summerbell C., Cameron C., Glasziou P., 2003. Should we recommend low-fat diets for obesity? Obes. Rev. 4 (2), 83-90.

Radzymińska M., Smoczyński S.S., Kopeć M., 2008. Persistent organochlorine pesticides, lead, cadmium, nitrate (V) and nitrate (III) in Polish milk and dairy products. Polish J. Environ. Stud. 17 (1), 95-100.

Sasaki K., Nishioka T., Ishizuka Y., Saeki M., Kawashima T., Irie M., Mitsumoto M., 2007. Comparison of sensory traits and preferences between food co-product fermented liquid (FCFL)-fed and formula-fed pork loin. Asian-Aust. J. Anim. Sci. 20, 1272-1277.

Snijder M.B., van der Heijden A.A., van Dam R.M., Stehouwer C.D., Hiddink G.J., Nijpels G., Heine R.J., Bouter L.M., Dekker J.M., 2007. Is higher dairy consumption 
Winiarska-Mieczan A., 2014. Assessment of the risk of exposure to cadmium and lead as a result of the consumption of low-fat dairy products by expectant and lactating women. Acta Sci. Pol., Technol. Aliment. 13(2), 213-223.

associated with lower body weight and fewer metabolic disturbances? The Hoorn Study. Am. J. Clin. Nutr. 85, 989-995.

Sobczak M., Jabłoński E., 2007. Składniki mineralne w diecie kobiet ciężarnych i karmiących. Cz. 1. Makrominerały: wapń, magnez, fosfor, sód, potas, chlor [Mineral elements in diet of pregnant and breast-feeding women. Part 1. Macro minerals: calcium, magnesium, phosphorus, sodium, potassium, chloride]. Przegl. Lek. 64 (3), 165-169 [in Polish].

Starska K., Wojciechowska-Mazurek M., Mania M., Brulińska-Ostrowska M., Biernat U., Karłowski K., 2011. Noxious elements in milk and milk products in Poland. Polish J. Environ. Stud. 20 (4), 1043-1051.

Sughis M., Penders J., Haufroid V., Nemery B., Nawrot T.S., 2011. Bone resorption and environmental exposure to cadmium in children: a cross - sectional study. Environ. Health 10, 104-109.

Suliga E., 2011. Nutritional behaviours of pregnant women. Pediat. Endocrinol. Diabet. Metab. 17 (2), 76-81.
Sunyecz J.A., 2008. The use of calcium and vitamin D in the management of osteoporosis. Ther. Clin. Risk Manag. 4 (4), 827-836

Szkoda J., Żmudzki J., 1996. Zawartość pierwiastków toksycznych w mleku krowim i serach. Bromat. Chem. Toksykol. 4, 375-380.

Waszkowiak K., Szymandera-Buszka K., Szewczyk M., 2010. Udział produktów mlecznych jako źródła jodu w diecie kobiet ciężarnych [The contribution of dairy products to iodine intake in pregnant women's diet]. Probl. Hig. Epidemiol. 91 (4), 560-563 [in Polish].

WHO, 2001. Healthy eating during pregnancy and breast feeding. Booklet for mothers. [online], www.euro.who.int.

Winiarska-Mieczan A., Kwiecień M., Dymek T., 2007. Źródła białka w diecie studentów lubelskich uczelni [Sources of protein in the Lublin students diets]. Żyw. Czł. Metab. 5, 1517-1524 [in Polish].

Wojtyła A., Bojar I., Boyle P., Zatoński W., Marcinkowski J.T., Biliński P., 2011. Nutritional behaviours among pregnant women from rural and urban environments in Poland. Ann. Agric. Environ. Med. 18, 169-174.

\section{OSZACOWANIE RYZYKA NARAŻENIA NA KADM I OŁÓW KOBIET CIĘŻARNYCH I LAKTUJĄCYCH W WYNIKU SPOŻYWANIA PRODUKTÓW MLECZNYCH O OBNIŻONEJ ZAWARTOŚCI TŁUSZCZU}

\section{STRESZCZENIE}

Wstęp. Celem badań było oszacowanie ryzyka związanego ze spożywaniem produktów mlecznych o zredukowanej zawartości tłuszczu przez kobiety w okresie ciąży i laktacji.

Materiat i metody. Metodą ankietową sprawdzono popularność tych produktów wśród kobiet ciężarnych i laktujących, a następnie zbadano zawartość $\mathrm{Cd}$ i $\mathrm{Pb}$ w produktach nabiałowych o obniżonej zawartości thuszczu.

Wyniki. W grupie kobiet ciężarnych spożywających nabiał produkty mleczne o obniżonej zawartości thuszczu spożywało niemal 93\% respondentek, wśród kobiet laktujących odsetek sięgał 90\%. Mleko oraz jogurty owocowe były najchętniej wybierane przez kobiety zarówno ciężarne, jak i laktujące. Stwierdzono, że badane produkty o obniżonej zawartości tłuszczu nie zawierały więcej $\mathrm{Cd}$ i $\mathrm{Pb}$ niż odpowiednie produkty standardowe.

Wnioski. Biorąc pod uwagę deklarowane przez respondentki spożycie mleka oraz produktów mlecznych o zredukowanej zawartości tłuszczu, należy uznać je za bezpieczne pod względem zawartości $\mathrm{Cd}$ i Pb. Maksymalna podaż $\mathrm{Cd}$ i $\mathrm{Pb}$ w obu grupach kobiet nie przekraczała 3\% TWI oraz 2\% $\mathrm{BMDL}_{10}$.

Słowa kluczowe: kobiety laktujące, kobiety ciężarne, produkty mleczne niskotłuszczowe, $\mathrm{Cd}, \mathrm{Pb}$, narażenie

For citation - Do cytowania

Winiarska-Mieczan A., 2014. Assessment of the risk of exposure to cadmium and lead as a result of the consumption of low-fat dairy products by expectant and lactating women. Acta Sci. Pol., Technol. Aliment. 13(2), 213-223. 